\title{
Pengaruh Konsentrasi KOH dan Waktu Alkalisasi serta Umur Panen Kappaphycus alvarezii terhadap Karakteristik Mutu Karagenan Murni
}

\author{
Influence of $\mathrm{KOH}$ concentration and duration of alkalization and cultivation period of \\ Kappaphycus alvarezii on quality characteristic of refined carrageenan
}

\author{
Lukman Junaidi, Tiurlan F. Hutajulu, Agus Sudibyo, Nami Lestari dan Tita Aviana
}

Balai Besar Industri Agro

Jl. Ir. H. Juanda No, 11 Bogor 16122

lukmanjunaidi@gmail.com

\section{Riwayat Naskah:}

Diterima 04, 2018

Direvisi 05, 2018

Disetujui 05, 2018

\begin{abstract}
ABSTRAK: Indonesia memiliki potensi besar untuk pengembangan industri berbasis rumput laut. Salah satu jenis rumput laut yang potensial untuk dikembangkan adalah Kappaphycus alvarezii untuk produksi karagenan. Untuk mendukung upaya tersebut dilakukan penelitian pengaruh konsentrasi $\mathrm{KOH}$ dan waktu alkalisasi serta umur panen Kappaphycus alvarezii terhadap karakteristik mutu karagenan murni. Perlakuan yang diamati meliputi konsentrasi $\mathrm{KOH} \mathrm{(6 \% ,} \mathrm{8 \%} \mathrm{dan} \mathrm{10 \% ),} \mathrm{lama}$ proses alkalisasi (1 dan 2 jam) dan umur panen Kappaphycus alvarezii (14 dan 30 hari). Hasil penelitian menunjukkan variasi konsentrasi $\mathrm{KOH}$ dan umur panen memberikan pengaruh nyata terhadap karakteristik mutu karagenan. Sedangkan lama proses alkalisasi tidak memberikan pengaruh nyata. Hasil uji beda nyata terkecil (BNT) menunjukkan bahwa konsentrasi $\mathrm{KOH} 8 \%$ berbeda nyata dengan konsentrasi $\mathrm{KOH} 6 \%$ dan 10\%. Dengan demikian dapat disimpulkan bahwa perlakuan yang terbaik adalah penggunaan konsentrasi KOH 8\%. Sedangkan interaksi perlakuan yang menghasilkan karakteristik mutu karagenan terbaik adalah penggunaan konsentrasi $\mathrm{KOH} 8 \%$, umur panen 30 hari, dengan waktu alkalisasi 2 jam, yang memberikan nilai rendemen 41.09\%, kekuatan gel 868,56 $\mathrm{g} / \mathrm{cm}^{2}$, viskositas $38,22 \mathrm{cps}$, dan derajat putih $69,11 \%$.
\end{abstract}

Kata kunci: K. alvarezii, karagenan, alkalisasi, kekuatan gel, viskositas, derajat putih

ABSTRACT: Indonesia has great potential for the development of seaweed-based industries. One type of seaweed that have very good potential to develop is Kappaphycus alvarezii for the production of carrageenan. To support the effort, the research of Effect of $\mathrm{KOH}$ concentration and alkalization duration and harvest time of Kappaphycus alvarezii on the quality characteristics of refined carrageenan quality has been conducted. The variation of treatments included $\mathrm{KOH}$ concentration (6\%, $8 \%$ and $10 \%)$, alkalization process duration (1 and 2 hours) and harvest time of Kappaphycus alvarezii (14 and 30 days). The results showed variation of $\mathrm{KOH}$ concentration and harvest time gave a significance influence on carrageenan quality characteristics. While alkalization process duration did not give a significance influence. The least significant difference (LSD) test result showed that $\mathrm{KOH}$ concentration $8 \%$ was significantly different with $\mathrm{KOH}$ concentration $6 \%$ and $10 \%$. Thus it can be concluded that the best treatment was using of $\mathrm{KOH}$ concentration $8 \%$. While the treatment interaction which produced the best quality characteristics of carrageenan was the use of KOH concentration $8 \%, 30$ days harvest time and 2 hours alkalization, giving the value of yield $41.09 \%$, gel strength $868,56 \mathrm{~g} / \mathrm{cm} 2$, viscosity $38,22 \mathrm{cps}$, and whiteness degree $69.11 \%$.

Keywords: K. alvarezii, carrageenan, alkalization, gel strength, viscosity, whiteness

\section{Pendahuluan}

Indonesia sebagai negara kepulauan memiliki potensi yang sangat besar untuk pengembangan komoditas rumput laut. Rumput laut (seaweed) termasuk kelompok makroalga yang banyak hidup melekat di dasar perairan dan tergolong dalam 
divisi thallophyta. Klasifikasi rumput laut berdasarkan kandungan pigmen terdiri dari 4 kelas, yaitu rumput laut hijau (Chlorophyta), rumput laut merah (Rhodophyta), rumput laut coklat (Phaeophyta) dan rumput laut pirang (Chrysophyta) (Sahri, 2018). Jenis rumput laut yang banyak terdapat di perairan Indonesia adalah Gracilaria, Gelidium, Eucheuma, Hypnea, Sargasum dan Tubrinaria (Anonym, 2013 dan Mulyati \& Geldermann, 2017).

Rumput laut alam biasanya dapat hidup di atas substrat pasir dan karang mati. Selain hidup bebas di alam, beberapa jenis rumput laut juga banyak dibudidayakan oleh sebagian masyarakat pesisir Indonesia. Contoh jenis rumput laut yang banyak dibudidayakan diantaranya adalah Kappaphycus alvarezii dan Gracilaria sp. Beberapa daerah dan pulau di Indonesia dimana masyarakat pesisirnya banyak melakukan usaha budidaya rumput laut yaitu diantaranya di Kepulauan Seribu, Provinsi Kepulauan Riau, Pulau Lombok, Sulawesi, Maluku dan Papua. Pada Gambar 1 ditunjukkan rumput laut dari jenis Kappaphycus alvarezii.

Untuk meningkatkan nilai tambah potensi rumput laut tersebut perlu dilakukan penganekaragaman produk olahan. Salah satu produk olahan yang potensial dari rumput laut adalah karagenan. Kappaphycus alvarezii atau sering disebut Eucheuma cottonii merupakan jenis rumput laut yang paling utama sebagai penghasil karagenan (Munoz, Freile-Pelegrin and Robledo, 2014). Kappaphycus alvarezii banyak dijumpai di pesisir laut Indonesia, Malaysia dan Filipina (Bono, Anisuzzaman and Ding, 2014).

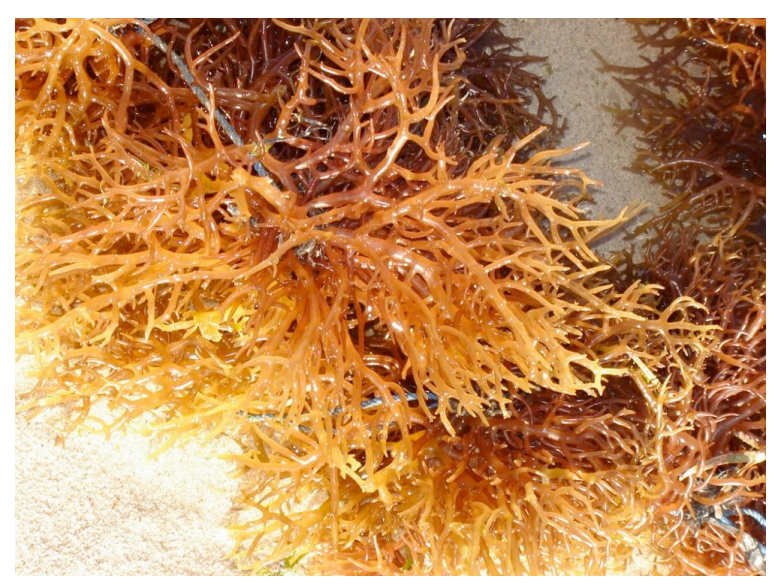

Gambar 1. Kappaphycus alvarezii

Beberapa jenis Kappaphycus alvarezii mempunyai peranan penting dalam perdagangan internasional sebagai penghasil ekstrak karagenan. Besarnya kandungan karagenan dari rumput laut dari jenis yang sama sangat dipengaruhi oleh lokasi tempat tumbuhnya. Kandungan karagenan dalam rumput laut berkisar 54 - 73\% (Periyasamy, Anantharaman, Balasubramanian and Rao, 2014;
Khambhaty et al. 2012; Wenno, Thenu dan Lopulalan, 2012).

Karagenan adalah senyawa polisakarida yang diekstrak dari alga merah yang memiliki komposisi D-galactose dan 3,6-anhydrogalactose yang berikatan dengan $\alpha-1,3$ dan $\beta-1,4$ glycosidic (Manuhara, Praseptiangga and Riyanto, 2016 dan Campo, Kawano, Braz da Silva and Carvalho, 2009). Karagenan merupakan senyawa hidrokoloid yang terdiri dari campuran amonium, kalsium, magnesium, kalium dan natrium sulfat ester dari galaktosa dan kopolimer 3-6 anhidrogalaktosa (Earle, Ayalasomayajula, Loknadh, Reddy and Kanth, 2016). Karagenan merupakan polisakarida berantai linear dengan berat molekul di atas 100 $\mathrm{kDa}$. Rantai polisakarida tersebut terdiri dari ikatan berulang antara gugus galaktosa dengan 3,6anhidrogalaktosa (3,6 AG), keduanya baik yang berikatan dengan sulfat maupun tidak, dihubungkan dengan ikatan glikosidik $\alpha-(1,3)$ dan $\beta-(1,4)$ (Jiao, Yu, Zhang and Ewart, 2011; Nurmiah, 2013 dan Bono et al. 2014). Struktur molekul berbagai jenis karagenan ditunjukkan pada Gambar 2.
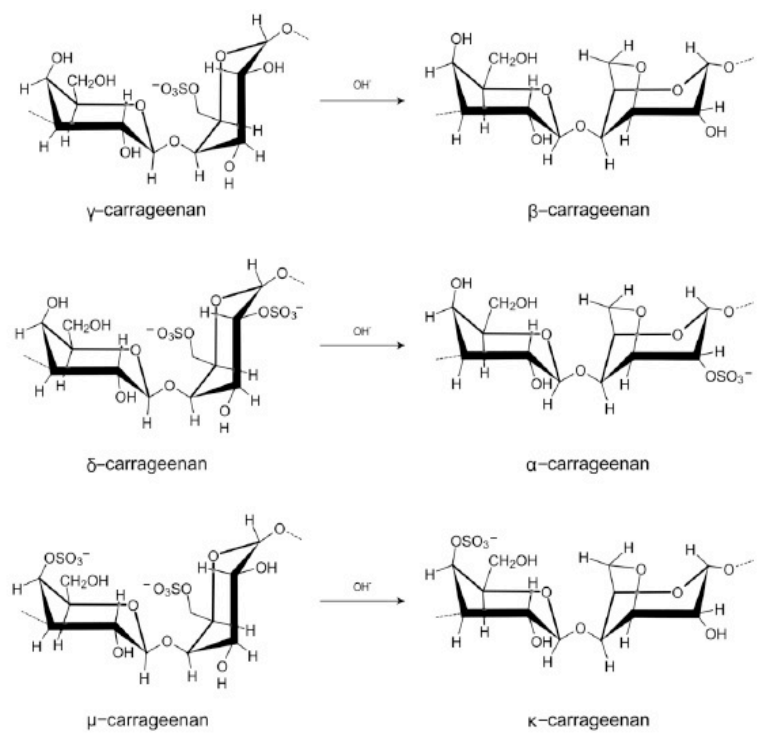

Gambar 2. Struktur molekul karagenan (Jiao et al. 2015)

Karagenan umumnya digunakan dalam industri pangan dan non pangan, seperti: emulsifier, gelling and binding agent, thickener, stabilizer, pharmaceuticals, kosmetik, formulasi untuk printing dan tekstil (Ali, Ruslan, Sulaiman dan Yasir, 2014).

Penggunaan karagenan secara komersil dipengaruhi oleh struktur makromolekul yang menentukan nilai viskositas dan gelling properties dari karagenan tersebut (Hayashi et al. 2017 dan Serowik, Figiel, Nejman, Pudlo, Chorazyk and Kopec, 2017).

Beberapa penelitian terkait produksi karagenan telah dilakukan. Manuhara et al (2016) melakukan 
penelitian penggunaan $\mathrm{KCl}$ untuk ekstraksi karagenan dari Kappaphycus alvarezii asal Karimun Jawa, dan menyimpulkan penggunaan larutan $\mathrm{KCl}$ 2.5\% memberikan hasil karagenan yang terbaik. Widyastuti (2010) melakukan ekstraksi karagenan dari Eucheuma cottonii dan E. spinosum dari berbagai umur panen, dan menyimpulkan umur panen 45 hari memberikan hasil karagenan yang lebih baik. Ali et al (2014) melakukan optimasi proses ekstraksi karagenan dari rumput laut $K$. Striatum menggunakan pelarut $\mathrm{KCl}$ dan etanol, dan menyimpulkan kondisi proses optimal untuk ekstraksi karagenan adalah suhu ekstraksi $80^{\circ} \mathrm{C}$ selama 50 menit menggunakan larutan KCL 0.25 dan etanol $80 \%$.

Terdapat berbagai hasil penelitian terkait dengan rendemen proses produksi karagenan dari Kappaphycus alvarezii. Bono et al (2014) menyebutkan waktu ekstraksi tidak mempengaruhi rendemen dan viskositas karagenan, tetapi suhu ekstraksi dapat mempengaruhi rendemen proses. Distantina, Fadilah, Danarto, Wiratni dan Fahrurrozi (2009) menyebutkan semakin tinggi konsentrasi $\mathrm{KCl}$ dalam proses ekstraksi akan semakin besar rendemen proses produksi karagenan, tetapi dapat menurunkan kekuatan gel. Namun demikan cukup sulit untuk membandingkan secara kualitatif maupun kuantitatif hasil penelitian tersebut, mengingat rendemen sangat dipengaruhi oleh metode ekstraksi dan jenis Kappaphycus alvarezii yang digunakan (Ilias, Ismail and Othman, 2017).

Tujuan penelitian ini adalah untuk mengevaluasi pengaruh konsentrasi $\mathrm{KOH}$ dan waktu alkalisasi serta umur panen Kappaphycus alvarezii terhadap karakteristik mutu karagenan murni. Informasi tersebut diharapkan dapat dimanfaatkan untuk proses produksi karagenan di industri.

\section{Bahan dan Metode}

\subsection{Bahan}

Bahan baku yang digunakan dalam penelitian ini adalah rumput laut merah jenis Kappaphycus alvarezii asal Lombok. Rumput laut yang dipanen oleh petani pada saat berumur 14 hari dan 30 hari kemudian dikeringkan dibawah sinar matahari hingga kadar air mencapai 35\%. Bahan kimia yang digunakan untuk ekstraksi adalah $\mathrm{KOH}, \mathrm{KCL}$, filter aid / diatomet, isopropil alkohol.

\subsection{Alat}

Peralatan yang digunakan adalah alat ekstraktor, timbangan analitik, timbangan kasar, alat filter, kertas $\mathrm{pH}$.

\subsection{Metode}

\subsubsection{Pembuatan karagenan murni}

Tahapan proses yang digunakan dalam proses produksi karagenan murni ditunjukkan pada Gambar 3 (Basmal, 2005). Kappaphycus alvarezii dicuci dengan air bersih sebanyak 5 kali pencucian, kemudian ditiriskan dan direndam dalam larutan KOH (pH 8-9) selama 24 jam. Setelah perendaman dilakukan penirisan dan dilanjutkan dengan proses alkalisasi.

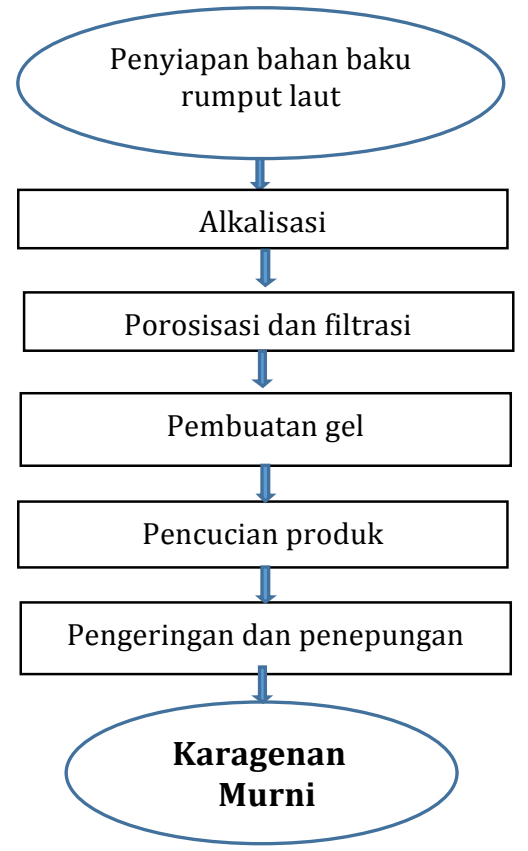

Gambar 3. Diagram alir proses produksi karagenan murni

Proses alkalisasi (alkalization process) dilakukan dengan variasi konsentrasi larutan alkali $\mathrm{KOH} \mathrm{6 \% ,}$ $8 \%$ dan $10 \%$ serta lama proses 1 dan 2 jam. Proses alkalisasi rumput laut dengan menggunakan pengekstrak $\mathrm{KOH}$ dilakukan dengan pemanasan dalam wadah stainless steel yang sudah berisi air pada suhu $75^{\circ} \mathrm{C}$. Ke dalam wadah stainless steel yang berisi air panas di tuangkan rumput laut bersih dengan perbandingan, air : rumput laut = 15:1 (v/b).

Ke dalam bubur rumput laut kemudian ditambahkan filter aid sebanyak $2 \%$ per bobot rumput laut, sambil diaduk (proses porosisasi). Cairan/bubur rumput laut dalam keadaan panas dimasukkan kedalam mesin filter (filter compressor). Prinsip kerja alat ini adalah menyaring dengan memberi tekanan udara sebesar 85 psi di atas bahan yang akan disaring. Penyaring yang digunakan adalah kain saring (bahan satin dengan ukuran 200 mesh) setebal dua lapis dengan poripori yang halus. Kemudian hasil filtrat yang diperoleh ditimbang.

Filtrat yang dihasilkan kemudian dilanjutkan pada proses pembuatan gel dengan cara dipanaskan dalam wadah stainless steel pada suhu $90^{\circ} \mathrm{C}$, lalu ditambahkan larutan $\mathrm{KCl} 3 \%$ dan diaduk 
selama 2 jam. Gel kemudian dituangkan kedalam cetakan yang terbuat dari wadah stainless steel, dibiarkan membeku hingga satu malam. Produk karagenan yang telah membeku dicuci dengan larutan $\mathrm{KCl} 1$ - 1,5\% dalam wadah sambil diaduk selama 1 jam, kemudian disaring dan dibekukan pada suhu $10^{\circ} \mathrm{C}$.

Karagenan yang sudah dibekukan kemudian dikeringkan dibawah sinar matahari selama beberapa hari atau diberi isopropil alkohol untuk mempercepat pengeringan untuk mencapai kadar air produk 8 - 10\%. Produk kering digiling sampai 60 mesh hingga menjadi tepung produk karagenan murni berwarna putih.

\subsubsection{Analisis}

Analisis yang dilakukan meliputi analisis: rendemen, kekuatan gel, viskositas dan derajat putih. Rendemen diukur dengan membandingkan bobot karagenan murni dengan bobot rumput laut kering (Munoz, Freile-Pelegrin dan Robledo, 2016), dengan rumus: Rendemen $=(\mathrm{Wc} / \mathrm{Wds}) \times 100 ; \mathrm{di}$ mana: Wc: bobot karagenan murni dan Wds: bobot rumput laut kering yang diekstrak. Kekuatan gel dan viskositas diuji menggunakan metode yang diuraikan pada SNI 8391-1:2017, dan derajat putih menggunakan SNI 3451:2011.

Metode analisis data yang digunakan adalah analisis statistik. Rancangan percobaan yang digunakan adalah rancangan acak lengkap faktorial dengan 3 faktor, yaitu: (1) variasi konsentrasi larutan alkali $\mathrm{KOH}: 6 \%, 8 \%$ dan 10\%, (2) lama proses alkalisasi: 1 dan 2 jam, dan (3) umur panen Kappaphycus alvarezii: 14 hari dan 30 hari. Percobaan diulang sebanyak 2 kali dengan Model rancangan sebagai berikut (Harjosuwono, Arnata dan Puspawati, 2011):

$\begin{aligned} \text { Yijk }= & \mu+\alpha \mathrm{i}+\beta \mathrm{J}+\chi \mathrm{k}+(\alpha \beta) \mathrm{ij}+(\alpha \chi) \mathrm{ik}+(\beta \chi) \mathrm{jk}+ \\ & (\alpha \beta \chi) \mathrm{ijk}+\varepsilon \mathrm{ijk} \\ \mathrm{Yijk}= & \text { respon setiap variabel pengamatan } \\ \mu \quad & \text { nilai tengah (rata-rata) dari seluruh } \\ & \text { pengamatan. } \\ \alpha \mathrm{i} \quad & \text { pengaruh variasi konsentrasi larutan alkali } \\ & \text { KOH taraf ke-i (i=1.2.3) } \\ \beta \mathrm{j} \quad & \text { pengaruh lama proses alkalisasi taraf ke- } \mathrm{j} \\ & (\mathrm{j}=1.2) \\ \chi \mathrm{k} \quad & \text { pengaruh umur panen Kappaphycus } \\ & \text { alvarezii ke-k }(\mathrm{k}=1.2) \\ (\alpha \beta) \mathrm{ij}= & \text { pengaruh interaksi variasi konsentrasi }\end{aligned}$ larutan alkali $\mathrm{KOH}$ ke-i (i=1.2.3) dengan variasi lama proses alkalisasi taraf ke-j $(j=1.2)$

$(\alpha \chi) \mathrm{ik}=$ pengaruh interaksi variasi konsentrasi larutan alkali KOH ke-i (i=1.2.3) dengan variasi umur panen Kappaphycus alvarezii taraf ke-k $(\mathrm{k}=1.2)$ $(\beta c) \mathrm{jk}=$ pengaruh pengaruh variasi lama proses alkalisasi ke-j ( $\mathrm{j}=1.2)$ dengan variasi umur panen Kappaphycus alvarezii taraf ke-k $(\mathrm{k}=1.2)$

$(\alpha \beta c)$ ijk = pengaruh interaksi variasi konsentrasi larutan alkali $\mathrm{KOH}$ ke-i (i=1.2.3) dengan variasi lama proses alkalisasi taraf ke-j $(\mathrm{j}=1.2)$ dan variasi umur panen Kappaphycus alvarezii taraf ke-k $(\mathrm{k}=1.2)$

$\varepsilon i j=\quad$ galat dari percobaan.

Data dianalisa dengan metode univariate general model dengan program SPSS versi 17. Untuk melihat taraf perlakuan yang berbeda, dilakukan uji lanjut Beda Nyata Terkecil (BNT) pada tingkat kepercayaaan $95 \%$.

\section{Hasil dan Pembahasan}

Evaluasi terhadap pengaruh perlakuan variasi konsentrasi $\mathrm{KOH}$, lama proses ekstraksi dan umur panen pada proses produksi karagenan murni didasarkan pada: rendemen proses dan karakteristik mutu karagenan berupa kekuatan gel, viskositas, dan derajat putih.

\subsection{Rendemen proses}

Hasil analisis terhadap rendemen proses produksi karagenan murni, ditunjukkan pada Gambar 4, untuk bahan baku Kappaphycus alvarezii yang dipanen pada umur 14 hari dan 30 hari.

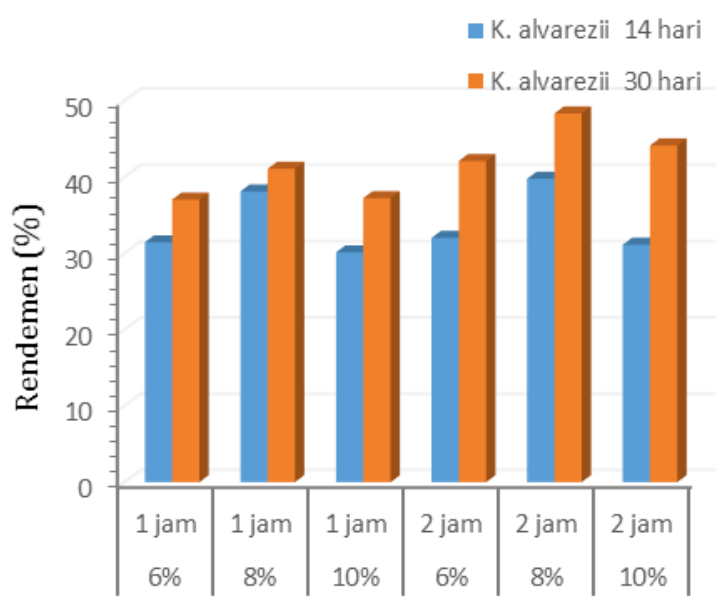

Konsentrasi $\mathrm{KOH}$ dan waktu ekstraksi

Gambar 4. Pengaruh konsentrasi KOH dan waktu ekstraksi
terhadap rendemen karagenan murni pada umur panen Kappaphycus alvarezii 14 hari dan 30 hari

Berdasarkan data pada Gambar 4, dapat dilihat bahwa konsentrasi $\mathrm{KOH}(6 \%, 8 \%$ dan 10\%) dan umur panen (14 hari dan 30 hari) berpengaruh terhadap rendemen proses produksi karagenan murni. Sedangkan lama proses ekstraksi (1 jam 
dan 2 jam) tidak memberikan pengaruh nyata terhadap rendemen proses karagenan murni.

Hal ini dapat disimpulkan berdasarkan uji BNT (beda nyata terkecil) yang memberikan nilai BNT untuk perlakuan $\mathrm{KOH}$ terhadap rendemen proses, sebesar 1,84. Nilai selisih rata-rata (mean difference) antara perlakuan $\mathrm{KOH} 8 \%$ dengan $\mathrm{KOH}$ $6 \%$, sebesar 6,33 dan KOH 10\% sebesar 6,05. Nilai selisih rata-rata yang lebih besar dari nilai BNT menunjukkan bahwa perlakuan $\mathrm{KOH} \quad 8 \%$ memberikan perbedaan nyata terhadap rendemen proses dibandingkan dengan perlakuan $\mathrm{KOH} 6 \%$ dan $10 \%$.

Untuk lama ekstraksi 1 jam, peningkatan konsentrasi $\mathrm{KOH}$ dari $6 \%$ menjadi $8 \%$ dapat meningkatkan rendemen proses dari 32,04\% menjadi 38,11\% (untuk Kappaphycus alvarezii umur 14 hari) dan dari 42,12\% menjadi 48,34\% (untuk Kappaphycus alvarezii umur 30 hari). Sedangkan peningkatan konsentrasi $\mathrm{KOH}$ dari $8 \%$ menjadi $10 \%$, mengakibatkan penurunan rendemen proses dari $38,11 \%$ menjadi $32,12 \%$ (untuk Kappaphycus alvarezii umur 14 hari) dan dari 48,34\% menjadi 44,15\% (untuk Kappaphycus alvarezii umur 30 hari).

Untuk lama ekstraksi 2 jam, peningkatan konsentrasi $\mathrm{KOH}$ dari $6 \%$ menjadi 8\% dapat meningkatkan rendemen proses dari $31,45 \%$ menjadi 39,78\% (untuk Kappaphycus alvarezii umur 14 hari) dan dari 37,06\% menjadi 41,09\% (untuk Kappaphycus alvarezii umur 30 hari). Sedangkan peningkatan konsentrasi $\mathrm{KOH}$ dari 8\% menjadi $10 \%$, mengakibatkan penurunan rendemen proses dari 39,78\% menjadi 31,13\% (untuk Kappaphycus alvarezii umur 14 hari) dan dari 41,09\% menjadi 37,25\% (untuk Kappaphycus alvarezii umur 30 hari).

Pada proses alkalisasi gugus hidroksida dari $\mathrm{KOH}$ meresap ke Kappaphycus alvarezii dan menghilangkan sulfat group dalam karagenan melalui reaksi desulfurisasi pada posisi 6-unit galaktosa dari karagenan untuk menciptakan perulangan 3,6 anhidro-D-galaktosa (3,6-AG), sementara anion $\left(\mathrm{K}^{+}\right)$mampu menetralkan muatan dari kelompok sulfat yang dihilangkan dengan menggabungkan bersama membentuk kalium sulfat (Mustapha, Chandar, Abidin, Saghravani and Harun, 2011). Semakin lama proses ekstraksi, semakin baik interaksi larutan alkali dengan Kappaphycus alvarezii, dan diharapkan rendemen dapat meningkat. Namun demikian proses alkalisasi yang terlalu lama ( $>4$ jam) dapat mengakibatkan penghancuran karagenan secara berlebihan dan dengan demikian dapat mempengaruhi kekuatan gel (Ilias et al. 2017).

Gambar 4 menunjukkan umur panen Kappaphycus alvarezii berpengaruh terhadap peningkatan rendemen proses. Penambahan umur panen Kappaphycus alvarezii dari 14 hari menjadi
30 hari dapat meningkatkan rendemen proses dari $38.11 \%$ menjadi $48.34 \%$ (untuk KOH 8\% dan lama ekstraksi 1 jam) serta dari 39.78\% menjadi $41.09 \%$ (untuk KOH 8\% dan lama ekstraksi 2 jam).

Rendemen tertinggi diperoleh dengan perlakukan konsentrasi $\mathrm{KOH} 8 \%$, lama proses ekstraksi 2 jam, dan umur panen 30 hari, yaitu sebesar 48,34\%. Sedangkan rendemen terendah dihasilkan oleh perlakuan konsentrasi $\mathrm{KOH} \mathrm{10 \% ,}$ lama proses ekstraksi 1 jam, dan umur panen 14 hari, yaitu sebesar $30.12 \%$. Hal ini sejalan dengan hasil penelitian Widyastuti (2010) yang menyebutkan umur panen E. cottonii mempengaruhi kandungan karagenannya. Penambahan umur panen E. cottonii akan meningkatkan kandungan karagenannya. E. cottonii yang dipanen umur 15 hari memiliki kadar karagenan sekitar $40 \%$ dan meningkat menjadi sekitar $50 \%$ pada umur 45 hari.

\subsection{Kekuatan gel}

Hasil analisis terhadap kekuatan gel produk karagenan murni, ditunjukkan pada Gambar 5 untuk bahan baku Kappaphycus alvarezii yang dipanen pada umur 14 hari dan 30 hari.

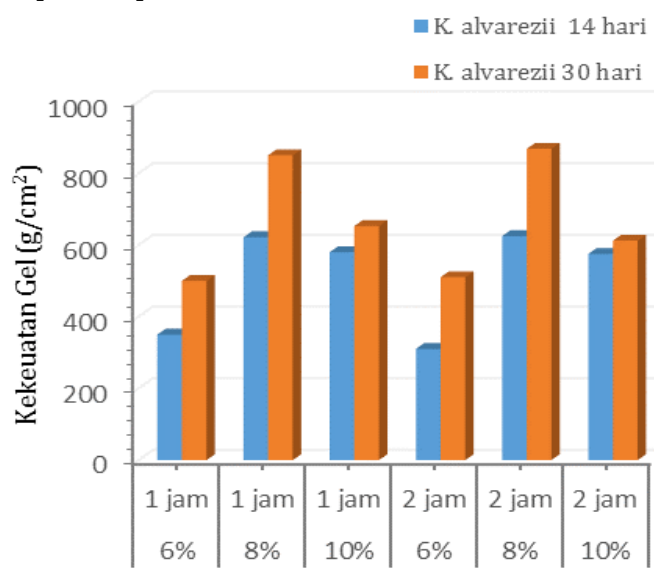

Konsentrasi $\mathrm{KOH}$ dan waktu ekstraksi

Gambar 5. Pengaruh konsentrasi $\mathrm{KOH}$ dan waktu ekstraksi terhadap kekuatan gel karagenan murni pada umur panen Kappaphycus alvarezii14 hari dan 30 hari

Berdasarkan data pada Gambar 5, dapat dilihat bahwa konsentrasi KOH (6\%, 8\% dan 10\%) dan umur panen (14 hari dan 30 hari berpengaruh terhadap nilai kekuatan gel produk karagenan murni. Sedangkan lama proses ekstraksi (1 jam dan 2 jam) tidak memberikan pengaruh nyata terhadap rendemen proses karagenan murni.

Hal ini dapat disimpulkan berdasarkan uji BNT untuk perlakuan $\mathrm{KOH}$ terhadap nilai kekuatan gel karagenan murni, sebesar 2,23. Nilai selisih ratarata (mean difference) antara perlakuan $\mathrm{KOH} \mathrm{8 \%}$ dengan $\mathrm{KOH} 6 \%$, sebesar 32.38 dan $\mathrm{KOH} 10 \%$ sebesar 13.63. Nilai selisih rata-rata yang lebih besar dari nilai BNT menunjukkan bahwa 
perlakuan KOH 8\% memberikan perbedaan nyata terhadap kekuatan gel karagenan murni dibandingkan dengan perlakuan KOH 6\% dan 10\%.

Untuk lama ekstraksi 1 jam, peningkatan konsentrasi $\mathrm{KOH}$ dari $6 \%$ menjadi $8 \%$, dapat meningkatkan nilai kekuatan gel dari $350,34 \mathrm{~g} / \mathrm{cm}^{2}$ menjadi $622,1 \mathrm{~g} / \mathrm{cm}^{2}$ (untuk Kappaphycus alvarezii umur 14 hari) dan dari $500,17 \mathrm{~g} / \mathrm{cm}^{2}$ menjadi $850,55 \mathrm{~g} / \mathrm{cm}^{2}$ (untuk Kappaphycus alvarezii umur 30 hari). Sedangkan peningkatan konsentrasi $\mathrm{KOH}$ dari $8 \%$ menjadi $10 \%$, mengakibatkan penurunan nilai kekuatan gel dari $622,1 \mathrm{~g} / \mathrm{cm}^{2}$ menjadi 580,24 $\mathrm{g} / \mathrm{cm}^{2}$ (untuk Kappaphycus alvarezii umur 14 hari) dan dari 850,55 g/ $/ \mathrm{cm}^{2}$ menjadi $653,12 \mathrm{~g} / \mathrm{cm}^{2}$ (untuk Kappaphycus alvarezii umur 30 hari).

Untuk lama ekstraksi 2 jam, peningkatan konsentrasi $\mathrm{KOH}$ dari $6 \%$ menjadi 8\%, dapat meningkatkan nilai kekuatan gel dari $310,34 \mathrm{~g} / \mathrm{cm}^{2}$ menjadi 625,11 g/ $\mathrm{cm}^{2}$ (untuk Kappaphycus alvarezii umur 14 hari) dan dari $510,33 \mathrm{~g} / \mathrm{cm}^{2}$ menjadi 868,56 g/cm ${ }^{2}$ (untuk Kappaphycus alvarezii umur 30 hari). Sedangkan peningkatan konsentrasi $\mathrm{KOH}$ dari $8 \%$ menjadi $10 \%$, mengakibatkan penurunan rendemen proses dari $625,11 \mathrm{~g} / \mathrm{cm}^{2}$ menjadi $575,3 \mathrm{~g} / \mathrm{cm}^{2}$ (untuk Kappaphycus alvarezii umur 14 hari) dan dari $868,56 \mathrm{~g} / \mathrm{cm}^{2}$ menjadi $612,34 \mathrm{~g} / \mathrm{cm}^{2}$ (untuk Kappaphycus alvarezii umur 30 hari). Gambar 4 menunjukkan umur panen Kappaphycus alvarezii sangat berpengaruh terhadap peningkatan nilai kekuatan gel. Penambahan umur panen Kappaphycus alvarezii dari 14 hari menjadi 30 hari dapat meningkatkan nilai kekuatan gel dari 622,1 $\mathrm{g} / \mathrm{cm}^{2}$ menjadi $850,55 \mathrm{~g} / \mathrm{cm}^{2}$ (untuk KOH $8 \%$ dan lama ekstraksi 1 jam) serta dari $625,11 \mathrm{~g} / \mathrm{cm}^{2}$ menjadi $868,56 \mathrm{~g} / \mathrm{cm}^{2}$ (untuk $\mathrm{KOH} 8 \%$ dan lama ekstraksi 2 jam).

Nilai kekuatan gel tertinggi diperoleh dengan perlakukan konsentrasi $\mathrm{KOH} 8 \%$, lama proses ekstraksi 2 jam, dan umur panen 30 hari, yaitu sebesar $868,56 \mathrm{~g} / \mathrm{cm}^{2}$. Sedangkan kekuatan gel terendah dihasilkan oleh perlakuan konsentrasi KOH $10 \%$, lama proses ekstraksi 1 jam, dan umur panen 14 hari, yaitu sebesar $310,34 \mathrm{~g} / \mathrm{cm}^{2}$.

Karagenan merupakan polimer linier yang disusun oleh residu D-galaktosa-4-sulfat dengan ikatan $\alpha$ pada posisi 1,3 dan residu 3,6-anhidro-Dgalaktosa dengan ikatan $\beta$ pada posisi 1,4 (Nurmiah, 2013). Adanya gugus 6-sulfat, dapat menurunkan daya gelasi dari karagenan. Pemberian alkali pada karagenan dapat mengakibatkan terjadinya reaksi trans-eliminasi gugus 6-sulfat, yang menghasilkan 3,6 anhydro-Dgalaktosa. Hal ini dapat meningkatkan derajat keseragaman molekul dan menambah daya gelasi dari karagenan (Nurmiah, 2013). Alkali pada proses ekstraksi mampu mengkatalisis hilangnya gugus 6-sulfat yang bersifat hidrofilik dari unit monomer karagenan dan membentuk 3,6- anhydrogalaktosa yang bersifat hidrofobik sehingga dapat meningkatkan kekuatan gel karagenan (Nurmiah, 2013).

\subsection{Viskositas}

Hasil analisis terhadap viskositas produk karagenan murni, ditunjukkan pada Gambar 6 untuk bahan baku Kappaphycus alvarezii yang dipanen pada umur 14 hari dan 30 hari.

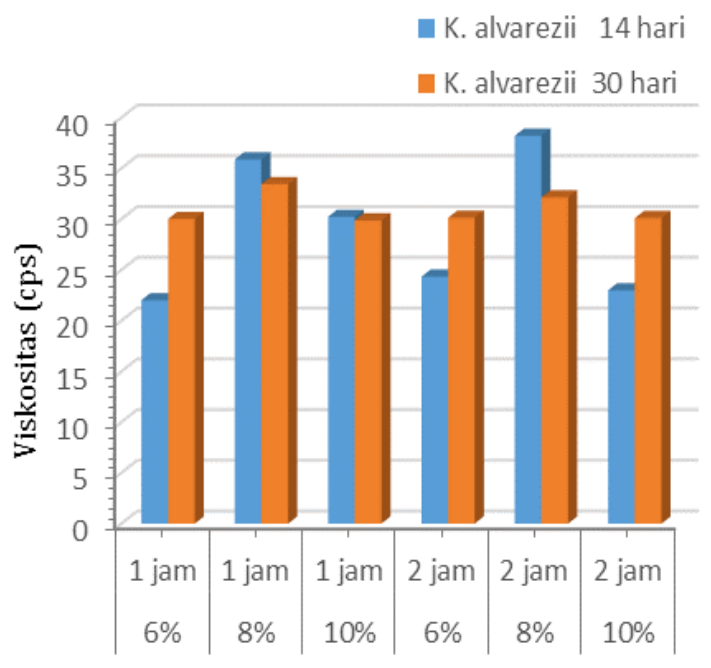

Konsentrasi KOH dan waktu ekstraksi

Gambar 6. Pengaruh konsentrasi KOH dan waktu ekstraksi terhadap viskositas karagenan murni pada umur panen Kappaphycus alvarezii 14 hari dan 30 hari

Berdasarkan data pada Gambar 6, dapat dilihat bahwa konsentrasi $\mathrm{KOH}(6 \%, 8 \%$ dan 10\%) dan umur panen (14 hari dan 30 hari berpengaruh terhadap nilai viskositas produk karagenan murni. Sedangkan lama proses ekstraksi ( 1 jam dan 2 jam) tidak memberikan pengaruh nyata terhadap rendemen proses karagenan murni.

Hal ini dapat disimpulkan berdasarkan uji BNT untuk perlakuan $\mathrm{KOH}$ terhadap nilai viskositas karagenan murni, sebesar 1,76. Nilai selisih ratarata (mean difference) antara perlakuan $\mathrm{KOH} 8 \%$ dengan $\mathrm{KOH} 6 \%$, sebesar 8,26 dan $\mathrm{KOH} 10 \%$ sebesar 6,61. Nilai selisih rata-rata yang lebih besar dari nilai BNT menunjukkan bahwa perlakuan $\mathrm{KOH}$ $8 \%$ memberikan perbedaan nyata terhadap viskositas karagenan murni dibandingkan dengan perlakuan $\mathrm{KOH} 6 \%$ dan $10 \%$.

Untuk lama ekstraksi 1 jam, peningkatan konsentrasi $\mathrm{KOH}$ dari $6 \%$ menjadi $8 \%$, dapat meningkatkan nilai viskositas dari 22,01 cps menjadi 35,88 cps (untuk Kappaphycus alvarezii umur 14 hari) dan dari 30,02 cps menjadi 33,45 cps (untuk Kappaphycus alvarezii umur 30 hari). Sedangkan peningkatan konsentrasi KOH dari 8\% menjadi $10 \%$, mengakibatkan penurunan nilai viskositas dari 35,88 cps menjadi 30,23 cps (untuk Kappaphycus alvarezii umur 14 hari) dan dari 33,45 cps menjadi 29,88 cps (untuk Kappaphycus alvarezii umur 30 hari). 
Untuk lama ekstraksi 2 jam, peningkatan konsentrasi $\mathrm{KOH}$ dari $6 \%$ menjadi $8 \%$, dapat meningkatkan nilai viskositas dari 24,34 cps menjadi 38,22 cps (untuk Kappaphycus alvarezii umur 14 hari) dan dari 30,14 cps menjadi 32,15 cps (untuk Kappaphycus alvarezii umur 30 hari). Sedangkan peningkatan konsentrasi $\mathrm{KOH}$ dari 8\% menjadi $10 \%$, mengakibatkan penurunan nilai viskositas dari 38,22 cps menjadi 22,99 cps (untuk Kappaphycus alvarezii umur 14 hari) dan dari 32,15 cps menjadi 30,11 cps (untuk Kappaphycus alvarezii umur 30 hari).

Gambar 6 menunjukkan umur panen Kappaphycus alvarezii sangat berpengaruh terhadap nilai viskositas produk karagenan murni. Penambahan umur panen Kappaphycus alvarezii dari 14 hari menjadi 30 hari dapat menurunkan nilai viskositas dari 35,88 cps menjadi 33,45 cps (untuk KOH 8\% dan lama ekstraksi 1 jam) serta dari 38.32 cps menjadi 32,15 cps (untuk $\mathrm{KOH} 8 \%$ dan lama ekstraksi 2 jam).

Penurunan nilai viskositas tersebut diduga dipengaruhi oleh kadar abu karagenan. Hal tersebut relevan dengan meningkatnya rendemen proses produksi karagenan dan kekuatan gel sejalan dengan penambahan umur panen, yang secara teoritis diyakini bahwa kedua faktor tersebut dapat menurunkan nilai viskositas karagenan (Widyastuti, 2010). Umur panen Kappaphycus alvarezii dapat mempengaruhi kadar abu karagenan (Wenno et al., 2012). Selanjutnya disebutkan bahwa kadar abu tertinggi didapatkan pada Kappaphycus alvarezii yang dipanen pada umur 55 hari dan terendah pada umur panen 40 hari. Meningkatnya waktu panen cenderung menyebabkan kadar abu dari tepung karagenan meningkat.

Nilai viskositas tertinggi diperoleh dengan perlakukan konsentrasi $\mathrm{KOH} 8 \%$, lama proses ekstraksi 2 jam, dan umur panen 14 hari, yaitu sebesar 38,22 cps. Sedangkan nilai viskositas terendah dihasilkan oleh perlakukan konsentrasi $\mathrm{KOH}$ 6\%, lama proses ekstraksi 1 jam, dan umur panen 30 hari, yaitu sebesar 22,01 cps.

\subsection{Derajat Putih}

Hasil analisis terhadap derajat putih produk karagenan murni, ditunjukkan pada Gambar 7 untuk bahan baku Kappaphycus alvarezii yang dipanen pada umur 14 hari dan 30 hari. Hal ini dapat disimpulkan berdasarkan uji BNT untuk perlakuan $\mathrm{KOH}$ terhadap nilai derajat putih karagenan murni, sebesar 1,78. Nilai selisih ratarata (mean difference) antara perlakuan $\mathrm{KOH} 8 \%$ dengan $\mathrm{KOH} 6 \%$, sebesar 9.01 dan $\mathrm{KOH} 10 \%$ sebesar 4.63. Nilai selisih rata-rata yang lebih besar dari nilai BNT menunjukkan bahwa perlakuan $\mathrm{KOH}$ $8 \%$ memberikan perbedaan nyata terhadap derajat putih karagenan murni dibandingkan dengan perlakuan $\mathrm{KOH} 6 \%$ dan 10\%. Untuk lama ekstraksi 1 jam, peningkatan konsentrasi $\mathrm{KOH}$ dari 6\% menjadi $8 \%$, dapat meningkatkan nilai derajat putih dari 50,81\% menjadi 57,6\% (untuk Kappaphycus alvarezii umur 14 hari) dan dari 57,01\% menjadi $68,1 \%$ (untuk Kappaphycus alvarezii umur 30 hari). Sedangkan peningkatan konsentrasi $\mathrm{KOH}$ dari 8\% menjadi $10 \%$, mengakibatkan penurunan nilai derajat putih dari 57,6\% menjadi 55,67\% (untuk Kappaphycus alvarezii umur 14 hari) dan dari $68,1 \%$ menjadi $62,34 \%$ (untuk Kappaphycus alvarezii umur 30 hari).

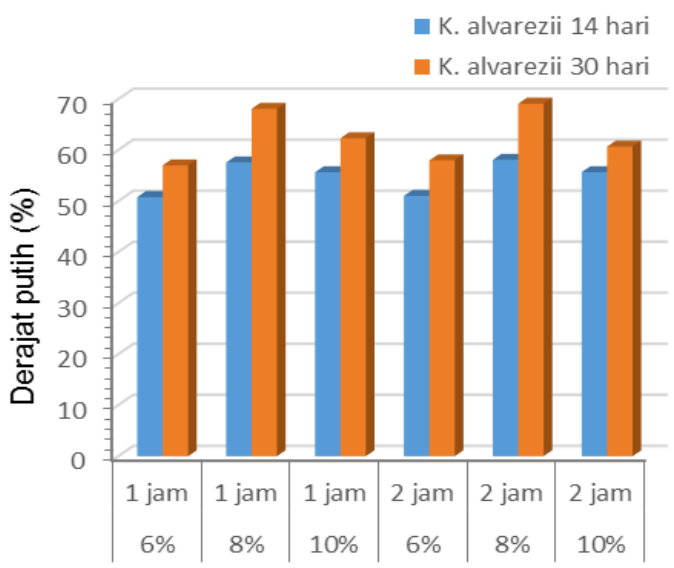

Konsentrasi $\mathrm{KOH}$ dan waktu ekstraksi

Gambar 7. Pengaruh konsentrasi KOH dan waktu ekstraksi terhadap derajat putih karagenan murni pada umur panen Kappaphycus alvarezii 14 hari dan 30 hari

Untuk lama ekstraksi 2 jam, peningkatan konsentrasi $\mathrm{KOH}$ dari $6 \%$ menjadi $8 \%$, dapat meningkatkan nilai derajat putih dari 51,05\% menjadi 58,09\% (untuk Kappaphycus alvarezii umur 14 hari) dan dari 57,99\% menjadi 69,11\% (untuk Kappaphycus alvarezii umur 30 hari). Sedangkan peningkatan konsentrasi $\mathrm{KOH}$ dari 8\% menjadi $10 \%$, mengakibatkan penurunan nilai derajat putih dari 57,6\% menjadi 55,67\% (untuk Kappaphycus alvarezii umur 14 hari) dan dari $69,11 \%$ menjadi 60,69\% (untuk Kappaphycus alvarezii umur 30 hari).

Gambar 7 menunjukkan umur panen Kappaphycus alvarezii berpengaruh terhadap peningkatan nilai derajat putih. Penambahan umur panen Kappaphycus alvarezii dari 14 hari menjadi 30 hari dapat meningkatkan nilai derajat putih dari $57,6 \%$ menjadi $68,1 \%$ (untuk $\mathrm{KOH}$ 8\% dan lama ekstraksi 1 jam) serta dari 58.09\% menjadi 69,11\% (untuk KOH 8\% dan lama ekstraksi 2 jam).

Nilai derajat putih tertinggi diperoleh dengan perlakukan konsentrasi KOH 8\%, lama proses ekstraksi 2 jam, dan umur panen 30 hari, yaitu sebesar 69,11\%. Sedangkan nilai derajat putih terendah dihasilkan oleh perlakukan konsentrasi 
$\mathrm{KOH} \mathrm{6 \% ,} \mathrm{lama} \mathrm{proses} \mathrm{ekstraksi} 1$ jam, dan umur panen 14 hari, yaitu sebesar 69,11\%.

Warna kecoklatan pada karagenan dapat disebabkan masih adanya selulosa, pigmen fikoeritin, dan fikosianin. Selain sebagai komponen yang tidak larut air, selulosa juga menyebabkan warna karagenan menjadi keruh (Imeson, 2000). Wenno et al (2012) menunjukkan bahwa penambahan umur panen di atas 40 hari berakibat penurunan derajat putih karagenan yang dihasilkan. Hal ini diduga, dengan pertambahan umur panen akan meningkatkan kandungan selulosa, yang merupakan komponen yang dapat mempengaruhi warna karagenan.

\section{Kesimpulan}

Berdasarkan hasil analisis sidik ragam rancangan percobaan acak faktorial, variasi konsentrasi larutan $\mathrm{KOH}$ (6\%, 8\%, dan 10\%), umur panen Kappaphycus alvarezii (14 hari dan 30 hari), dan interaksi perlakuan konsentrasi KOH dan umur panen berpengaruh nyata terhadap rendemen proses produksi karagenan murni, nilai kekuatan gel, viskositas; dan derajat putih. Hal ini ditunjukkan oleh nilai $\mathrm{F}$ hitung yang lebih besar dari F tabel serta nilai siginifikansi lebih kecil dari 0.05. Sedangkan perlakuan waktu alkalisasi (1 jam dan 2 jam) tidak berpengaruh nyata terhadap rendemen proses produksi karagenan murni, nilai kekuatan gel, viskositas dan derajat putih. Hal ini ditunjukkan oleh nilai $\mathrm{F}$ hitung yang lebih kecil dari F table serta nilai siginifikansi lebih besar dari 0.05 .

Hasil uji beda nyata terkecil (BNT) menunjukkan perlakuan konsentrasi KOH 8\% berbeda nyata dengan konsentrasi $\mathrm{KOH} 6 \%$ dan 10\%. Dengan demikian dapat disimpulkan bahwa perlakuan yang terbaik adalah penggunaan konsentrasi $\mathrm{KOH}$ 8\%. Sedangkan interaksi perlakuan yang menghasilkan karakteristik mutu karagenan terbaik adalah penggunaan konsentrasi KOH 8\%, umur panen 30 hari, dengan lama waktu alkalisasi 2 jam, yang memberikan nilai rendemen $41.09 \%$, kekuatan gel 868,56 $\mathrm{g} / \mathrm{cm}^{2}$, viskositas 38,22 cps, dan derajat putih $69,11 \%$.

\section{Ucapan Terima Kasih}

Penulis mengucapkan terima kasih kepada Kepala BBIA sebagai penanggungjawab unit tempat dilakukannya penelitian.

\section{Daftar Pustaka}

Ali, M.K.M., Ruslan, M.H., Sulaiman, J. \& Yasir, S.M. (2014) Optimization of Process Condition of Refined Carrageenan (RC) Produced from Seaweed Kappaphycus striatum Using Response Surface Methodology (RSM) In Malaysia. In International Symposium on Processing of Foods, Vegetables and Fruits, 154-159.
Anonym. (2013) Rumput Laut Indonesia - Warta Ekspor, Edisi September 2013. Kementerian Perdagangan RI.

[BSN] Badan Standardisasi Nasional. (2017) Standar Nasional Indonesia Karagenan Murni (Refined Carragenan): Bagian 1 Kappa Karagenan-Syarat Mutu dan Pengolahan-SNI 83911:2017. Badan Standardisasi Nasional, Jakarta.

[BSN] Badan Standardisasi Nasional. (2011) Standar Nasional Indonesia Tapioka-SNI 3451: 2011. Badan Standardisasi Nasional Jakarta.

Basmal, J., Suryaningrum, T.D., \& Aumelia, W. (2005) Effect of the concentration and ratio of potassium hydroxide and seaweed on the carrageenan paper quality. Journal of Indonesian Fisheries Research, 11(8), 29-38.

Bono, A., Anisuzzaman, S.M. \& Ding, O.W. (2012) Effect of process conditions on the gel viscosity and gel strength of semi-refined carrageenan (SRC) produced from seaweed (Kappaphycus alvarezii). Journal of King Saud University Engineering Sciences, 26, 3-9

Campo, V.L., Kawano, D.F., Braz da Silva Jr., D. \& Carvalho, I. (2009) Carrageenans: biological properties, chemical modifications and structural analysiseA review. Carbohydr. Polym., 77, 167-180.

Distantina, S. Fadilah, Danarto, Y.C., Wiratni \& Fahrurrozi, M. (2009) Pengaruh kondisi proses pada pengolahan Eucheuma cottonii terhadap rendemen dan sifat gel karagenan. Ekuilibrium, 8(1), 35 - 40

Earle, R.R., Ayalasomayajula, L.U., Loknadh, G., Reddy, K.S.R.K. \& Kanth, L.R. (2016) A review on natural polymers used in pharmaceutical dosage forms International Journal of Science and Research Methodology (IJSRM Human), 3(3), 7788.

Harjosuwono, B.A., Arnata, I.W. \& Puspawati, G.A.K.D. (2011) Rancangan Percobaan Teori, Aplikasi SPSS dan Excel. Lintas Kata Publishing, Malang.

Hayashi, L., Oliveira, E.C., Bleicher-Lhonneur, G., Boulenguer, P., Pereira, R.T., von Seckendorff, R., Shimoda, V.T., Leflamand, A., Vallée, P. \& Critchley, A.T. (2007) The effects of selected cultivation conditions on the carrageenan characteristics of Kappaphycus alvarezii (Rhodophyta, Solieriaceae) in Ubatuba Bay, Sao Paulo, Brazil. Journal of Applied Phycology, 19(5), 505.

Ilias, M.A., Ismail, A. \& Othman, R. (2017) Analysis of carrageenan yield and gel strength of kappaphycus species in Semporna Sabah. J. Trop. Plant Physiol, 9, 14-23

Imeson, A.P. (2000) Carrageenan. Handbook of hydrocolloids. Wood Head Publishing. Cambridge England, 87-102.

Jiao, G., Yu, G., Zhang, J. \& Ewart, H.S. (2011) Chemical structures and bioactivities of sulfated polysaccharides from marine algae. Marine Drugs, 9(2), 196-223.

Khambhaty, Y., Mody, K., Gandhi, M.R., Thampy, S., Maiti, P. Brahmbhatt, H., Eswaran, K. \& Ghosh, P.K. (2012) Kappaphycus alvarezii as a source of bioethanol. Bioresource technology, 103(1), 180-185

Manuhara, G.J., Praseptiangga, D. \& Riyanto, R.A. (2016) Extraction and characterization of refined K-carrageenan of red algae [Kappaphycus Alvarezii (Doty ex PC Silva, 1996)] Originated from Karimun Jawa Islands. Aquatic Procedia, 7, 106-111.

Mulyati, H. \& Geldermann, J. (2017) Managing risks in the Indonesian seaweed supply chain. Clean Technologies and Environmental Policy, 19(1), 175-189.

Munoz, J., Freile-Pelegrin, Y., \& Robledo, D. (2004) Mariculture of Kappaphycus alvarezii (Rhodophyta, Solieriaceae) colour strains in tropical waters of Yucatan, Mexico. Aquaculture, $239,161-177$.

Mustapha, S., Chandar, H., Abidin, Z.Z., Saghravani, R. \& Harun, M.Y. (2011) Production of semi-refined carrageenan from Eucheuma cotonii. Journal of Scientific \& Industrial Research, 70, 865-870.

Nurmiah, S. (2013) Proses produksi karagenan skala pilot plant dari rumput laut Kappaphycus alvarezii dan pemetaan potensinya. Thesis S3 IPB. Bogor.

Periyasamy, C., Anantharaman, P., Balasubramanian, T. \& Rao, P.S. (2014) Seasonal variation in growth and carrageenan 
Citation: Junaidi, L., Hutajulu, TF., Sudibyo, A., Lestari, N., Aviana, T. (2018). Pengaruh Konsentrasi KOH dan Waktu Alkalisasi serta Umur Panen Kappaphycus alvarezii terhadap Karakteristik Mutu Karagenan Murni. Warta IHP, 35(1),20-28

Halaman $\mid 28$

yield in cultivated Kappaphycus alvarezii (Doty) Doty on the coastal waters of Ramanathapuram district, Tamil Nadu. Journal of Applied Phycology, 26(2), 803-810.

Sahri, A. (2018) Mengenal potensi rumput laut: kajian pemanfaatan sumber daya rumput laut dari aspek industri dan kesehatan. Majalah Ilmiah Sultan Agung, 44(118), 95116

Serowik, M., Figiel, A., Nejman, M., Pudlo, A., Chorazyk, D. \& Kopec, W. (2017) Drying characteristics and some properties of spouted bed dried semi-refined carrageenan. Journal of Food Engineering, 194, 46-57.

Wenno, M.R., Thenu, J.L. \& Lopulalan, C.G.C. (2012) Karakteristik kappa karagenan dari Kappaphycus alvarezii pada berbagai umur panen. Jurnal Pascapanen dan Bioteknologi Kelautan dan Perikanan, 7(1), 61-68

Widyastuti, S. (2010) Sifat fisik dan kimiawi karagenan yang diekstrak dari rumput laut Eucheuma cottonii dan E. spinosum pada umur panen yang berbeda. Agroteksos, 20(1), $41-50$ 